JONAH ALICE ALADI,

\title{
SOCIAL TECHNOLOGIES FOR SOLVING HUMANITARIAN PROBLEMS: EXPERIENCE OF NIGERIA
}

The goal of the paper is give substantiations of social technologies as means of curbing the problem. In particular, the role of the media as an instrument of attraction of Nigerian young people to participate in entrepreneurship. Reflection of entrepreneurial perspectives of Nigerian youth are stated from the viewpoint of two competing theories - neoliberal and political-economic theories. The first of them provides an explanation of informal entrepreneurship as a result of rational decision of economical subjects to work in informal economics by reason of burdensome regulatory environment; the second explains the work of entrepreneurs in informal economy by insufficient state interference, limited capability of consultations and remote possibility of small business support at initial stage of its development. It is shown that in Nigeria these theories are rather complementary than competing. The clear evidence of this statement are empirical observations. The author's research is based on two assumptions of agenda-setting theory: the first is that the press and the media do not reflect reality, they filter and shape it; the second is that media concentration on a few issues and subjects leads the public to perceive those issues as more socially important than other issues. Based on this theory, it can be argued that if the media set proper agenda on the issue, it will have effect on construction of relative worldview attitudes of the youth. In the conclusion it is shown that entrepreneurship in Nigeria is considered as promising method of creating workplaces for unemployed school and higher education graduates, therefore attraction of young people to the entrepreneurship can tackle the humanitarian challenges that the country is facing. Over the course of many years the governmental policy of Nigeria did not succeed in creating favorable institutional environment for the entrepreneurship development. The climate that is present there nowadays is the main deterrent in process of self-sufficiency and creation of economic autonomy, what leads to increase of unemployment, vandalism and other social defects in the young country. The media is the factor that influences on the development of the entrepreneurship by means of creating relevant discourse, which transmits values and images ascribed to entrepreneurship, encourages an entrepreneurial spirit in the society and becomes an instrument of attraction of youth to participate in entrepreneurship. Possible media technologies of support to the entrepreneurial activities are outlined, in particular: regular reporting the success stories of entrepreneurs; transmitting entrepreneurial activity values among the youth by means of creating special media product; creating documentaries with the purpose to promote the entrepreneurship and demonstrate positive dynamics of its development; stimulation the government and banking sector to give preferential credits to future entrepreneurs through the use of corresponding advertisement tools.

Keywords: entrepreneurship; media; Nigeria; unemployment; youth.

Introduction: Overview of unemployment in Nigeria. The growing rate of youth unemployment in Nigeria suggests the need for re-examining how to promote entrepreneurship as a way of curbing the problem. Each year, available tertiary institutions in Nigeria like Polytechnics, Monotechnics, Colleges of Education and Universities product graduates into the labour market without a corresponding space to accommodate them. Aside from that, there are others who finishes education at the Secondary School levels and those who are also not educated but looks for menial jobs.

The practical evidence of the growing unemployment in Nigeria usually comes to the fore each time there is an advertisement for national recruitment. For example, the Federal Government of Nigeria in 2013 advertised for recruitment into the Nigerian Immigration service, about 800,000 applicants indicated interest for just 4,000 slots. Even though all the applicants were asked to pay an application fee of 1,000 Nigerian naira, they did so with stoicism with the expectation that they were going to be offered jobs. However, the unexpected happened when on March 15, 2014, the day set aside for the recruitment test, about 20 applicants died in stampedes in the centers. Many others received injuries (Leadership, March 17, 2014). The next example is that the Police Service Commission had advertised to recruit 10,000 officers and men into its fold. The recruitment portals, which were opened on April 1, 2016, had many unemployed Nigerians sending their applications. C. Akpeji (2016) marks the situation as follows: 
"For those groping for proof that Nigerians seriously crave jobs, need not search any further but ask the operators of the police recruitment portal, who have in 12 days received more than 500,000 applications for consideration in advertised 10,000 positions."

This reality provides insight into the level of unemployment in Nigeria and the desperation for jobs. Also, The National Bureau of Statistics (2015) reported that unemployment rate for those within the ages of 15-24 rose to $17.8 \%$ in third quarter of 2015 , up from $14.9 \%$ in second quarter of the same year. The International Labour Organisation (ILO) states that 201 million people globally are unemployed and this may raise to 219 million by 2019 . With 7.5 million Nigerians technically unemployed, this means $4 \%$ of the worlds unemployed are Nigerians (National Bureau of Statistics, 2015). This reality has posed a problem to the successive governments in Nigeria. The Punch (2015) commented this as rethinking of job creation.

The growing unemployment has systematically reflected in the standard of life of people. A "Survey on quality of Life Conducted" by Philip Consulting (2015) showed that, "130 million people ( $76.47 \%$ of the population) do not have access to the essential factors required to enjoy a good quality of life. This is reflected in the current life expectancy of 54 years (eight years lower than Ghana and 20 years lower than Brazil". Philips Consulting, which carried out the survey, says the exercise involved an analysis of 10 essential factors that determine the quality of life of citizens. It says: "These were determined based on their relevance to Nigerian society and importance for economic development". The survey reveals that in spite of the significant economic growth recorded over the past years, basic infrastructure is still rated poorly by the majority of Nigerians in terms of their impact on the quality of life in the country. The survey states that "the standard of living for a society is determined by the access to wealth and material goods for those in specified area and is measured using some specific factors". It notes that in arriving at the indices used, it incorporated factors from the established "Quality of Life" and "Standard of Living" models. In all, 10 essential factors were selected based on their relevance and importance for economic growth, to determine the quality of life in Nigeria. The factors included: employment, education, power, health security, food, housing, transportation, water and sanitation. The conclusion of this report is that there is the need to combat this rising poverty resulting from growing unemployment.

Theoretical Framework. This study is founded on agenda setting theory. The Agenda theory describes the "ability of the news media to influence the salience of topics on the public agenda (Asemah, 2011). It is the creation of public awareness and concern of salient issues by the news media. Two basic assumptions underlie most research on agenda-setting:

1. The press and the media do not reflect reality; they filter and shape it;

2. Media concentration on a few issues and subjects leads the public to perceive those issues as more important than other issues.

The theory was proposed by Maxwell McCombs and Donald Shaw in 1972. It provides insight on how the media can set agenda on entrepreneurship. Based on this theory, it can be argued that if the media set proper agenda on the issue, it will have effect on the youth.

At the same time, the author considers the creation of entrepreneurial environment in Nigeria with the goal to use the potential of competitiveness as factor of social development (Aleksandrova, 2018).

\section{Entrepreneurship as a Tool for Job Creation}

Entrepreneurship has largely been considered as a way of creating jobs for the teeming unemployed graduates in Nigeria. The general opinion among stakeholders in the Nigerian project is that youths' involvements in entrepreneurship could ameliorate the challenges facing the country. Entrepreneurship is defined as any commercially driven activity that one engages him/herself in to become self-dependent and self-sufficient. G. Onuoha (2007) defined entrepreneurship as the practice of starting new organizations or revitalizing mature organizations, particularly new businesses generally in response to identified opportunities. The definition of $\mathrm{G}$. Onuoha places more emphasis on business ventures. The National Universities Commission defined entrepreneurship as self employment of any sort; the activity that involves identifying opportunities within the economic system; the creation of new organizations; the willingness and ability of an individual to seek out investment opportunities in an environment and be able to establish and run an enterprise successfully based on the identifiable opportunities. The definition of the National Universities Commission is broad. However, it leaves out of account the risk factor. S. Chand (2015) defines entrepreneurship as a process of actions of an entrepreneur (that is a person who engages in entrepreneurship) in search of something new and exploits such ideas into gainful opportunities by accepting the risk and uncertainty with the enterprise. The definition of $S$. Chand added a new dimension into the definition by adding risk taking. In an attempt to explain the concept of entrepreneurship, G.T. Lumpkin and G.G. Dess (1996) cited in M. Sadati Madhoushi, H. Delavari, M. Mehdivand and R. Mihandost (2011, p. 310) delineated five dimensions which underline entrepreneurial process to include innovativeness, risk taking, proactiveness, autonomy, and competitive aggressiveness. These skills are hereby explained:

Innovativeness is the tendency for somebody to engage in and support new ideas, novelty and experimentation that may result to new product or services.

Risk Taking refers to a person or firms tendency to engage in high risk project so as to achieve good objectives.

Proactiveness is the process of anticipating and acting on future needs by seeking new opportunities, which may or may not be related to present line of action.

Autonomy in the sense of entrepreneurial sense is an independent action by a team or individual to promote a vision or idea and see it through completion.

Competitive Aggressiveness is related to somebody or firm's tendency to intensely and directly challenge its competitors in order to outwit them.

In an attempt to arrive at a definition of entrepreneurship, S.O. Mokaya, M. Namusonge and D. Sikalieh (2012) did a study on "The concept of entrepreneurship; in pursuit of a universally acceptable definition". The study was secondary, involving detailed analysis of published materials on the subject matter. The researchers found that entrepreneurship is the heart of the modern business, a force behind innovative businesses that characterize the modern economy and a dynamic process of creating incremental wealth by individuals who engage in it. The result of the researchers also shows that there are many definitions of entrepreneurship as there have been many attempts to define it. However, entrepreneurship was defined as an action-oriented, involving immense creativity and innovativeness. Entrepreneurship can either be opportunity-based or necessity-based but without regard to the motivation, it is pursued as a viable career option 
by people of all works of live, levels and occupations. S.O. Mokaya et al also reported that there continues to be new thoughts on the subject and it is still an evolving concept with more room for study, discovery and development. The definition of S.O. Mokaya et al is unique because it is the outcome of a research. Although there is no evidence of a globally acceptable definition of entrepreneurship that the current researcher is aware of, the essense of entrepreneurship is creation of wealth through business related activities. For the purpose of this article, entrepreneurship has been operationalized as an innovation based business venture, greatly founded on risk, competitive sagacity, commitment and hard work which purpose is to create wealth through profit making and ultimately economic rejuvenation. Entrepreneurship has unique characteristics. S. Chand (2015) listed these characteristics as follows:

Economic and dynamic activity: Entrepreneurship is considered an economic activity because it implicates the creation and operation of an enterprise aimed at generating value and creating wealth optimum utilisation of scarce resources. Efforts are made to ensure that loss is minimized and profit maximized.

Related to innovation: Entrepreneurship entails a constant looking for new ideas. This reality demands that entrepreneurs must produce new ideas upon a large scale. Entrepreneurship compels an individual to assess continuously the existing modes of business operations so that more efficient and effective systems can be evolved and adopted. This requires properly studying the business environment.

Profit potential: The distinctive feature of entrepreneurship is attainment of profit. Therefore, the profit potential of any entrepreneurial activity is the driving force of action or inaction. The enterprise should not operate at a loss.

Risk bearing: Risk taking is a very essential component of entrepreneurship. It is considered that good entrepreneurs are not averse to risk.

Entrepreneurship plays a vital role in the economies of countries. The United States Department of State/Bureau of International Information Programs (n.d p.3) listed the importance of entrepreneurship thus:

- Entrepreneurship offers a greater possibility of achieving significant financial rewards than working for someone else.

- It provides the ability to be involved in the total operation of the business, from concept to design and creation, from sales to business operations and customer response.

- It offers the prestige of being the person in charge.

- It gives an individual the opportunity to build equity, which can be kept, sold, or passed on to the next generation.

- Entrepreneurship creates an opportunity for a person to make a contribution. Most new entrepreneurs help the local economy.

Today youths must be encouraged to participate in entrepreneurship. Therefore, it is very essential for them to think differently and activate their innovativeness. The Punch newspaper in its editorial of $17^{\text {th }}$ August 2015, notes:

Latest unfavourable figures on Nigeria's unemployment rate demand fresh thinking..... With unemployment rising well above the sub-regional average and turmoil in the foreign exchange and money markets, the government will need to come up with a workable economic plan that will deliver millions of jobs and rejuvenate the productive sectors. The starting point should be making entrepreneurship and innovation drive our economic growth..... Nigeria has lived with high unemployment for too long and now is the time to think outside the box. This is the time to unleash the forces that underpin the creation of knowledge, its diffusion and commercialisation through innovation, and the growth of entrepreneurship in the growth process.

The submission above provides guidance on the role of entrepreneurship in job creation. The media should serve its purpose in persuading youths to get involved in entrepreneurship.

Overview of Institutional Environment of Entrepreneurship in Nigeria

Knowledge of institutional environment of entrepreneurship in Nigeria is essential to be able to appreciate its potentials as a job creation instrument in Nigeria. Nigeria is regarded as a developing economy based on World Bank (2016) classification of countries economy which places Nigeria as a lower middle income with Gross National Income (GNI) per capita of $\$ 1,026-4,035$. It is important to add that beginning with the 2016 ranking of countries' economies, the World Bank has stopped ranking countries using nomenclature like developed and developing; rather, they use lower income, lower middle income, upper middle income and high income. Therefore, the entrepreneurship environment in these countries is not the same. Nigeria is also regarded as the country with an informal economy (ODA list 2016). Webb, Bruton, Tihanyi and Ireland (2011) explain an informal economy as consisting of economic activities that occur outside of formal institutional boundaries, but remain within informal institutional boundaries for large segments of society. The informal economy contributes $10-20 \%$ to the Gross Domestic Products (GDP) of developed economies and $60 \%$ of emerging economies. That means that the informal economy plays a significant role in the economic activities of Nigeria.

Two competing theoretical perspectives explain the participation of entrepreneurs in the informal economy. These perspectives are the neo-liberal perspective and political economy perspective. The one explains informal entrepreneurship as resulting from rational economic actors voluntarily deciding to operate in the informal economy due to the burdensome regulatory environment; the other posits that entrepreneurs operate in the informal economy as a result of too little state intervention, such as poor advice and support for small businesses when beginning (Williams \& Martinez, 2014). C. Williams and A. Martinez (2014) studied 595 small business owners in the United Kingdom in order to gain some insight into their participation in the informal entrepreneurship and reported that $20 \%$ of the owners said that they had traded informally when starting up their ventures; $41 \%$ of the entrepreneurs attributed their illegal trading to too little state intervention like a lack of government advice and support, $35 \%$ reported too much intervention like burdensome bureaucracy, high taxes, etc. and $24 \%$ reported a mix of both factors. The result of $\mathrm{C}$. Williams and A. Martinez revealed the role of both the neo-liberal perspective and political economy perspective as an institutional environment that determines the operation of entrepreneurship. These perspectives present an appropriate framework for understanding entrepreneurship environment in Nigeria. This is because, over the years, government policies in Nigeria have failed to create a favourable environment for prosperity of entrepreneurship. E.M. Onwuka, K. E. Ugwu, K. Ukpai (2014) did a study to investigate the impact of policy measures in entrepreneurship development in Nigeria using secondary sources derived from archival data such as thesis publications, scientific journals publications, African statistical year book, and World 
Fact-book, etc. The researchers found that Nigeria's entrepreneurs have experienced difficulties in doing business due to: Managerial challenges, technological problems, lack of credit facilities, lack of basic amenities or infrastructural facilities, lack of power supply; inconsistencies in government policies, political instability, lack of patronizing made-in Nigeria products among others. E. M. Onwuka at el also considered that to solve entrepreneurship development problems, government has introduced programs such as; World Bank SMEs 1 and 2 Loan Scheme, National Economic Reconstruction Fund (NERFUND), Peoples and Community Bank, Nigerian Bank of Commerce and Industry (NBCl), Export Processing Zone (EPZ), National Poverty Eradication, Advisory Agencies, etc. According to the researchers, these policy measures have played an insignificant role in entrepreneurship development. However, they work only on white papers and used by some corrupt government officials to embezzle national treasury.

The Nigerian entrepreneurship environment is not favourable. P. Adebayo (2015) considers that weak entrepreneurial climate has been a major constraint militating against the aspiration for self-reliance and economic autonomy and has resulted into increasing rate of unemployment, vandalism and other social vices among the youth in Nigeria. P. Adebayo also studied the relationship between government entrepreneurial programmes on youth SMEs participation in Nigeria. P. Adebayo surveyed 250 sample using the questionnaire that was undertaken through an online platform across the beneficiaries of federal governmental SMEs financial intervention schemes - Youth Enterprise with Innovation in Nigeria (YouWiN). The study concludes that government intervention programmes such as financial, infrastructural and capacity building is of paramount priority to new venture creation among the youth. The findings further reveal a significant positive correlation between availability of fund and new venture creation.

Available literature (e.g. Djankov, Tim Caralee, Ramalho, \& Andrei, 2010, Obaji, \& Olugu, Braunerhjelm, Ding \& Thulin, 2015, Martins, 2004) suggest that economic incentives like the taxing system, policy stability, availability of labour, access roads among others can serve as incentives for entrepreneurship. When these incentives are insufficient or lacking, this will have a corresponding influence on entrepreneurship. Developing countries like Nigeria suffer most when it comes to entrepreneurship. This means that an application of appropriate economic theory in the entrepreneurship environment of developing countries is desired. W. J. Baumol (1968) argues that any economic theory of entrepreneurship should consider how to reduce the marginal costs of an entrepreneur risk bearing. Incorporating entrepreneurship into the framework of economic broadens the theory mainly by showing the nature of increasing returns to scale, knowledge externalities and the role of human capital. This reality suggests the connection between entrepreneurship and economic development. The media in Nigeria owe it a duty to set agenda on the need to improve on the institutional environment of entrepreneurship for the youth to see its attractiveness.

O. Ihugba, A. Odii, and A. Njoku, (2013) therefore, highlighted the challenges of entrepreneurship in Nigeria as follows.

1. Lack of Credit Facilities: Potential Nigeria entrepreneurs encounter many difficulties when trying to access credit for their businesses. Though there is a wide range of financial institutions that offer business loans, they usually charge high interest rates deterring aspiring entrepreneurs.

2. Corruption: Widespread and all present corruption that makes the procurement of licenses, permits, goods and services from government agencies and even the payment of taxes and levies difficult without paying bribes and kickbacks.

3. Inconsistent Government Policies: Government inconsistency is really a difficult problem an entrepreneur will face if he want to succeed in Nigeria. Governance is something entrepreneurs have no control over; all entrepreneurs can do is to influence government's policy with respect to enacting favorable business laws.

4. Multiple Taxation: One other difficult problem that is encountered by majority of Nigerian entrepreneurs is multiple taxation. Although entrepreneurs in a country have a responsibility of funding the government through paying taxes, most of the taxes charged on entrepreneurs are not lawful and have the effect of increasing the cost of conduct of business.

5. Poor State of the Country's Infrastructure: The state of Nigeria's infrastructure is considered as awful for both entrepreneurs and the rest of the country's population. With the existing infrastructure deteriorating, and in some places it is non-existent, the cost of doing business has tremendously gone up. The state of the country's road network makes it hard for entrepreneurs in the agricultural sector to transport harvested produce from farms to processing factories. According to a report released by the World Bank, Nigeria's pace of socioeconomic development and growth is well below what we can achieve.

6. Failure to Adapt to the Changing Business Environment: Majority of those who venture into MSMEs (Micro, Small and Medium Enterprises) do so because of their need to make money and in almost all cases, such entrepreneurs lack relevant and adequate information about the businesses they engage in. In the event where problems arise, most of these business owners lack sufficient problem solving skills and in the end they find it hard to survive with the growth in the telecommunications sector since the introduction of GSM in 2002.

7. Low Standard of Education: There is no gain saying the fact that education plays a strong role in forming the burgeoning entrepreneur. The world today is a global village (McLuhan, 1962) and since an intending entrepreneur must be conversant and in tune with events around and about him, education becomes a critical factor in preparing and empowering the entrepreneur with the qualities required of him.

8. Security Issues: When there is no guarantee of security of lives and properties, it is difficult to run a successful venture.

9. Getting venture capital to finance entrepreneurial endeavour in Nigeria is very difficult because of the political and economic instability.

10. The policies of the Nigerian government are a barrier to the success of large-scale entrepreneurial success for many Nigerians. The government suffers with corruption and greed. The government systematically ignores laws that are already in place to promote free enterprise.

11. The lack of enforcement of Nigerian patent laws discourages entrepreneurs from commercializing their ideas and inventions.

12. The constant political disorders in the country greatly limits foreign investors who would be willing to provide resources for entrepreneurship in the country, which is very rich in natural resources. 
13. Political and social movements strongly affect the level of entrepreneurial activity in Nigeria. Religious intolerance and ethnic warfare limit country progress in some areas of the country.

14. Female entrepreneurs in Nigeria are often underestimated and overlooked, they are often hindered because of cultural barriers such as male/female role definitions that signifies women inherently inferior to men.

15. Entrepreneurship activity in Nigeria is primarily based on necessity. Most new enterprisers start their own business because of personal needs or circumstances. The aim of the person who starts business may have an impact on its further development. The business started without knowledge required for further working with it may not succeed.

16. Poor planning: Experts say individuals who have successfully managed major events are aware of the fact that success mostly come as a result of careful, systematic, strategic planning and hard work.

17. Poor product or service: The entrepreneur must understand the needs of his customers and look for ways to meet these needs via the product or service, which he offers to the market.

18. Nigeria is characterized as country with large growing and active population with sanitation life styles resulting in high demand for expensive foreign goods and services. Most citizens have negative attitude towards made in Nigeria goods/services, are highly religious to a point of intolerance in some states (Ihugba et al, 2013).

How the Media can Promote youth involvement in Entrepreneurship

The media have a significant role in promoting entrepreneurship. This is because, apart from bringing up ideas relating to entrepreneurship that could provoke a sound discourse, the media could also source for information from established entrepreneurs regarding how to be successful and relay same to the audience. M. Hang and V. Weezel (2013) note that media formats such as newspapers, TV and radio are important mediums to transmit cultural values and ideas. They can also help to structure people's perception of entrepreneurship so as to grow an entrepreneurship spirit in society. M. Hang and V. Weezel further captures thus:

Media play an important role in influencing the entrepreneurship phenomenon, by creating a discourse that transmits values and images ascribed to entrepreneurship, by providing a carrier promoting entrepreneurial practices, and by encouraging an entrepreneurial spirit in the society. In this way, media and entrepreneurship have an impact on each other.

The submission above provides guidance on how the media can promote entrepreneurship. J. Levie, M. Hart and M. Karim (2010) did a study "Impact of Media on Entrepreneurial Intentions and Actions" and the main conclusions are following:

- TV business reality programmes tend not to directly trigger actual entrepreneurial intentions or action. However, they have a positive effect on social norms and values and thereby influence both the desirability and feasibility entrepreneurship. In this context, they indirectly influence actual patterns of entrepreneurship.

- There is a synergetic association between the positive media coverage of entrepreneurs and enterprise campaigns such as Global Entrepreneurship Week. This is consistent with the view that positive media coverage complements policy initiatives designed to provide enterprise skills and support start ups. Actual start ups require both aspiration and the capacity to act. In this sense, positive media portrayals of enterprise may well be contributing to the effectiveness of these more concrete initiatives.

- The discernible effects of both enterprise campaigns and TV business reality programmes on entrepreneurial action are considerably lower than that of family and friends, work colleagues, education and training in university or college.

- In general, leading enterprise campaigns and TV business reality programmes provide useful input to the generation of an entrepreneur-friendly culture, but have an immediate effect on the entrepreneurial activity of relatively few participating individuals.

In conclusion, this article makes the following guidelines on how the media can promote entrepreneurship in Nigeria:

- Frequency of reportage of success stories of entrepreneurs: It is suggested that the media can encourage Nigerian youth to get involved by frequently reporting the success stories of entrepreneurs in Nigeria and beyond. It is believed that such efforts will trigger youth interest to venture in entrepreneurship. For example, when a youth hears that someone has become successful after venturing in entrepreneurship, the person will be motivated to follow the path taken by him/her.

- Portraying entrepreneurs in positive light: The media portrayal of entrepreneurs in positive light will be essential in triggering youth involvement in entrepreneurship. It is related to the fact that people generally like to be presented in positive light and by doing so will trigger the interest of youth in entrepreneurship.

- Interviewing successful entrepreneurs and presenting their views to the public. Successful entrepreneurs like Aliko Dangote have important tips that could be helpful to the youth when made available to them. Therefore, the media should therefore search for established entrepreneurs and make available their tips.

- The media should write editorials, commentaries and others features that educate the youth on the importance of entrepreneurship. This is very essential because it will provide life-changing tips to the youths.

- Documentaries should be packaged and relayed through the television so that youth could be educated on the dynamics of entrepreneurship.

- The media should prepare advocacy report suggesting ways of promoting entrepreneurship development. Banks and government should also be encouraged to make provision for soft loans for intending entrepreneurs.

\section{Conclusion and suggestions for further Studies}

The article concludes that the media should adopt different strategies that leads to the promotion of youth attraction to the entrepreneurship. This can deliver Nigeria from the embarrassment and security threat occasioned by the increasing youth unemployment in Nigeria. It is suggested that further studies should be conducted to find out the influence of media portrayal of entrepreneurs on Nigerian youth entrepreneurship intent and action. Also, a content analysis study is required to find out the direction of media coverage of entrepreneurial related activities. Finally, it is suggested that media should make more effort in promoting youth involvement in entrepreneurship.

\section{REFERENCES}

Adebayo, P. (2015). Impact of Government Entrepreneurial Programmes on Youth SMES Participation in Nigeria. International Journal of Economics and Business Management, 1(8): 65-70. 
Retrieved from https://iiardpub.org/get/IJEBM/VOL\%201/65-79.pdf (In English).

Akpeji, C. (2016, April 12) 500,000 apply for 10,000 police jobs in 12 days. Guardian. Retrieved from http://guardian.ng/news/ 500000-apply-for-10000-police-jobs-in-12-days/ (In English).

Aleksandrova, O. \& Omelchenko, Y. \& Popovich, O. (2018). Competition as a Factor of Social Development. Studia Warmińskie. Tom. 55. pp. 43-62. DOI: 10.31648/sw.3061.

Asemah, S. E. (2011). Selected mass media themes. Jos: University Press. (In English).

Baumol, W. J. (1968). Entrepreneurship in economic theory. The American Economic Review, 58. (2) 64-71 (In English).

Chand, S. (2015). Entrepreneurship: Characteristics, Importance, Types, and Functions of Entrepreneurship. Retrieved from http://www.yourarticlelibrary.com/entrepreneur/entrepreneurship-characteristicsimportance-types-and-functions-of entrepreneurship/5228/ (In English).

Djankov, S., Tim, G., Caralee, M., Ramalho, R. \& Andrei, S. (2010). The effect of corporate taxes on investment and entrepreneurship. American Economic Journal: Macroeconomics, 2(3), 31-64. DOI: 10.1257/mac.2.3.31 (In English)

Editorial (2014, August 2). Immigration job scam forgotten? Leadership newspaper. Retrieved from http://leadership.ng/ opinions/editorial/379760/immigration-job-scam-forgotten (In English).

Editorial (2015 August 17). Framing fresh approach to job creation. Punch. Retrieved from http://thecitizenng.com/publicaffairs/framing-fresh-approach-to-job-creation-punch/ (In English).

Hang, M. \& Weezel, V. (2013). Media and entrepreneurship: A survey of the literature relating Both Concepts. Retrieved from http://www.personal.psu.edu/amh13/e ship/hangandweezel.pdf (In English).

Ihugba, O., Odii, A. \& Njoku, A. (2013). Challenges and prospects of entrepreneurship in Nigeria. Academic Journal of Interdisciplinary Studies, 2(5), 25-36. DOI: http://dx.doi.org/10.5901/ ajis.2013.v2n5p25 (In English).

Levie, J., Hart, M. \& Karim, M. (2010). Impact of media on entrepreneurial intentions and actions. Retrieved from https:// www.gov.uk/government/uploads/system/-uploads/attachment_data/file/32243/11-773-impact-of-media-entrepreneurialintentions-actions.pdf (In English).

Madhuoshi, M. \& Sadati, A., Dalaveri, H., Mehdivand, M. \& Mihandost, R. (2011). Entrepreneurial Orientation and Innovation Performance: The Mediating Role of Knowledge of Management. Asian Journal. 3 (4), 310-316. Retrieved from http://maxwellsci.com/print/ajbm/v3-310-316.pdf (In English).

Martins, S. (2004). Barriers to entrepreneurship and business creation. European Entrepreneurship Cooperation. Retrieved from http://www.adrimag.com.pt/downloads/cooperacao/ Barriers\%20entrepreneurship\%20and\%20business\%20creation.pdf (In English).

McLuhan, M. (1962). The Gutenberg Galaxy: The Making of Typographic Man. Toronto: University of Toronto Press (In English).

Mokaya, S. O., Namusonge, M. \& Sikalieh, D. (2012). The Concept of Entrepreneurship; in pursuit of a Universally Acceptable Definition. International Journal of Arts and Commerce. (6), 128135. Retrieved from https://www.ijac.org.uk/images/frontlmages/ gallery/Vol. 1 No. 6 /13.pdf (In English).

National Bureau of Statistics (2015). Unemployment/ underemployment watch 3Q 2015. National Bureau of Statistics (In English).

Obaji, O. \& Olugu, M. (2014). The role of government policy in entrepreneurship development. Science. Journal of Business and Management, 2(4), 109-115. DOI: http://dx.doi.org/10.11648/ j.sjbm.20140204.12 (In English).

Onuoha, G. (2007). Entrepreneurship. AIST International Journal, 10, 20-32 (In English).

Onwuka, E. M., Ugwu, K. E., \& Ukpai K. (2014). The effect of policy measures on entrepreneurship development analysis of
Nigeria's experience. European Journal of Business and Management, 6(23), 270-276. Retrieve from https://iiste.org/Journals/ index.php/EJBM/article/view/23812/24383 (In English).

United States Department of State/Bureau of International Information Programs (n.d). Principles of entrepreneurship. Retrieved from http://www.ait.org.tw/infousa/zhtw/DOCS/enterp.pdf (In English).

Webb, J. W., et al. (2012). Research on entrepreneurship in the informal economy: Framing a research agenda. Journal of Business Venturing. 28(5): 598-614. DOI: 10.1016/j.jbusvent.2012.05.003 (In English)

Williams, C. \& Martinez, A. (2014). Do small business startups test-trade in the informal economy? Evidence from a UK survey. International Journal of Entrepreneurship and Small Business, 22, (1): 1-16. DOI: 10.1504/ijesb.2014.062127 (In English).

World Bank (2016). World Bank Ranking list of economies July 2016. Retrieved from https://www.google.com.ng (In English).

\section{LIST OF REFERENCE LINKS}

Adebayo P. Impact of Government Entrepreneurial Programmes on Youth SMES Participation in Nigeria. International Journal of Economics and Business Management. 2015. 1(8): 65-70. URL: https://iiardpub.org/get/IJEBM/VOL\%201/65-79.pdf (дата звернення 19.11.2018)

Akpeji C. 500,000 apply for 10,000 police jobs in 12 days. Guardian. 2016, April 12. URL: http://guardian.ng/news/500000apply-for-10000-police-jobs-in-12-days/ (дата звернення 14.11.2018).

Aleksandrova O. \& Omelchenko Y. \& Popovich O. Competition as a Factor of Social Development. Studia Warmińskie. 2018. Tom. 55. pp. 43-62. DOI: 10.31648/sw.3061 (дата звернення 02.01.2019).

Asemah S. E. Selected mass media themes. Jos: University Press, 2011.

Baumol W. J. Entrepreneurship in economic theory. The American Economic Review. 1968. 58. (2) 64-71.

Chand S. Entrepreneurship: Characteristics, Importance, Types, and Functions of Entrepreneurship, 2015. URL: http:// www.yourarticlelibrary.com/entrepreneur/entrepreneurshipcharacteristicsimportance-types-and-functions-ofentrepreneurship/5228/ (дата звернення 04.12.2018).

Djankov S., Tim G., Caralee M., Ramalho R. \& Andrei S. The effect of corporate taxes on investment and entrepreneurship. American Economic Journal: Macroeconomics, 2010. 2(3), 3164. DOI: 10.1257/mac.2.3.31 (дата звернення 14.12.2018).

Editorial. Immigration job scam forgotten? Leadership newspaper. 2014, August, 2. URL: http://leadership.ng/opinions/ editorial/379760/immigration-job-scam-forgotten (дата звернення 16.12.2018).

Editorial. Framing fresh approach to job creation. Punch. 2015, August, 17. URL: http://thecitizenng.com/public-affairs/ framing-fresh-approach-to-job-creation-punch/ (дата звернення 16.11.2018).

Hang M. \& Weezel V. Media and entrepreneurship: A survey of the literature relating Both Concepts, 2013. URL: http:// www.personal.psu.edu/amh13/e ship/hangandweezel.pdf (дата звернення 22.11.2018).

Ihugba O., Odii A. \& Njoku A. Challenges and prospects of entrepreneurship in Nigeria. Academic Journal of Interdisciplinary Studies. 2013. 2(5), 25-36. DOI: http://dx.doi.org/10.5901/ ajis.2013.v2n5p25.

Levie J., Hart M. \& Karim M. Impact of media on entrepreneurial intentions and actions. 2010. Retrieved from https://www.gov.uk/ government/uploads/system/-uploads/attachment data/file/32243/ 11-773-impact-of-media-entrepreneurial-intentions-actions.pdf (дата звернення 28.11.2018).

Madhuoshi M. \& Sadati A., Dalaveri H., Mehdivand M. \& Mihandost R. Entrepreneurial Orientation and Innovation Performance: The Mediating Role of Knowledge of Management. Asian 
Journal. 2011. № 3 (4), 310-316. URL: http://maxwellsci.com/ print/ajbm/v3-310-316.pdf (дата звернення 19.12.2018).

Martins S. Barriers to entrepreneurship and business creation. European Entrepreneurship Cooperation, 2004. URL: http:// www. adrimag.com.pt/downloads/co-operacao/Barriers\%20entrepreneurship\%20and\%20business\%20creation.pdf (дата звернення 24.12.2018).

McLuhan M. The Gutenberg Galaxy: The Making of Typographic Man. Toronto: University of Toronto Press, 1962.

Mokaya S., Namusonge M. \& Sikalieh D. The Concept of Entrepreneurship; in pursuit of a Universally Acceptable Definition. International Journal of Arts and Commerce. 2012. № 6, 128135. URL: https://www.ijac.org.uk/images/frontlmages/gallery/ Vol._1_No._6_/13.pdf (дата звернення 30.10.2018).

National Bureau of Statistics. Unemployment/ underemployment watch $3 Q$ 2015. National Bureau of Statistics.

Obaji O. \& Olugu M. The role of government policy in entrepreneurship development. Science. Journal of Business and Management. 2014. № 2(4), 109-115. DOI: http://dx.doi.org/ 10.11648/j.sjbm.20140204.12 (дата звернення 16.11.2018).

Onuoha G. Entrepreneurship. AIST International Journal. 2007. № 10, 20-32 (дата звернення 18.11.2018).
Onwuka E. M., Ugwu K. E., \& Ukpai K. The effect of policy measures on entrepreneurship development analysis of Nigeria's experience. European Journal of Business and Management. 2014. № 6(23), 270-276. URL: https://iiste.org/Journals/index.php/ EJBM/article/view/23812/24383 (дата звернення 26.10.2018).

United States Department of State/Bureau of International Information Programs (n.d). Principles of entrepreneurship. URL: http://www.ait.org.tw/infousa/zhtw/DOCS/enterp.pdf (дата звернення 30.10.2018).

Webb J. W. et al. Research on entrepreneurship in the informal economy: Framing a research agenda. Journal of Business Venturing. 2012. 28(5): 598-614. DOI: 10.1016/j.jbusvent.2012.05.003.

Williams C. \& Martinez A. Do small business start-ups testtrade in the informal economy? Evidence from a UK survey. International Journal of Entrepreneurship and Small Business. 2014. 22, (1): 1-16. DOI: 10.1504/ijesb.2014.062127 (дата звернення 06.10.2018).

World Bank 2016, World Bank Ranking list of economies July 2016. URL: https://www.google.com.ng (дата звернення 03.12.2018)

Іона Аліса Аладі,

Федеральна політехніка Біда (штат Нігер, Нігерія)

e-mail: alicejonahas@gmail.com,ORCID0000-0003-3836-7070

\section{СОЦІАЛЬНІ ТЕХНОЛОГІЇ ВИРІШЕННЯ ГУМАНІТАРНИХ ПРОБЛЕМ: ДОСВІД НІГЕРІЇ}

Метою статті є обґрунтування застосування соціальних технологій як засобу стримування проблеми. Зокрема розглядається роль 3МІ як інструмента залучення молоді Нігерії до підприємництва. Міркування про підприємницькі перспективи нігерійської молоді викладаються 3 точки зору двох конкуруючих теорій - неоліберальної та політекономічної. Перша пояснює неформальне підприємництво як результат раціонального рішення економічних суб'єктів працювати в неформальній економіці через обтяжливе регуляторне середовище; друга пояснює діяльність підприємців в неформальному секторі економіки недостатністю державного втручання, а також обмежених можливостей консультацій та мінімальної можливості підтримки малого бізнесу на початковому етапі його розвитку. Показано, що на теренах Нігерії ці теорії не так конкурують, як взаємодоповнюють одна одну, свідченням чого є відповідні емпіричні дані. Протягом багатьох років урядова політика в Нігерії не спромоглася створити сприятливе інституційне середовище для розвитку підприємництва, і наявний тут сьогодні слабкий підприємницький клімат є головним стримуючим фактором у процесах самозабезпечення та створення економічної автономії, що призвело до зростання безробіття, вандалізму та інших соціальних вад серед молоді країни. Авторське дослідження спирається на два основні припущення "теорії порядку денного": перше - преса та 3MI не відображають реальність, вони фільтрують і формують їі; друге - концентрація 3MІ на відображенні відповідних феноменів змушує громадськість сприймати ці питання як більш соціально значущі. 3 контексту цієї теорії випливає, що якщо ЗМІ встановлять відповідні настанови з соціально значущих питань, це вплине на формування відповідних світоглядних орієнтацій молоді. У висновках зазначено, що підприємництво в Нігерії розглядається як перспективний спосіб створення робочих місць для незайнятих випускників шкіл і закладів вищої освіти, тому залучення молоді до підприємництва може бути однією 3 відповідей на гуманітарні виклики, що стоять перед країною. Засоби масової інформації є засобом впливу на розвиток підприємництва шляхом створення відповідного дискурсу, що транслює цінності й позитивні образи підприємців, сприяє розповсюдженню підприємницького духу в суспільстві та є інструментом залучення молоді до підприємницької діяльності. Окреслено можливі технології ЗМІ у підтримці підприємницької діяльності, як-то: регулярні репортажі про успіхи підприємців; розповсюдження цінностей підприємницької активності серед молоді шляхом створення спеціального медійного продукту; створення документальних фільмів для пропагування підприємництва та демонстрації позитивної динаміки його розвитку; стимулювання уряду та банківської сфери для надання пільгових кредитів майбутнім підприємцям шляхом застосування відповідних інструментів реклами.

Ключові слова: підприємництво; медіа; Нігерія; безробіття; молодь.

(C) Jonah Alice Aladi

Надійшла до редакції: 03.01.2019

Прийнята до друку: 19.02.2019 